\title{
Crystal Structure of 1,3-Bis(4-nitrophenyl)triazenido- $\left.\kappa^{2} N^{1} N^{3}\right]-$ bis(triphenylphosphine)copper(I), $\left[\mathrm{Cu}\left(\mathrm{O}_{2} \mathrm{NC}_{6} \mathrm{H}_{4} \mathrm{NNNC}_{6} \mathrm{H}_{4} \mathrm{NO}_{2}\right)\left(\mathrm{C}_{18} \mathrm{H}_{15} \mathrm{P}\right)_{2}\right]$
}

\author{
Manfredo Hörner, *† Janaina Sartori BonINI,* Herton FenNer,* Jörg DANIELs, ** and \\ Johannes BECK**
}

*Departamento de Química, Universidade Federal de Santa Maria, Brazil

**Institut für Anorganische Chemie, Universität Bonn, Germany

\begin{abstract}
The reaction between $\left[\mathrm{CuCl}\left(\mathrm{PPh}_{3}\right)_{3}\right]$ and 1,3-bis(4-nitrophenyl)triazene deprotonated with metallic sodium in methanol yields crystalline $\left[\mathrm{Cu}\left(\mathrm{O}_{2} \mathrm{NC}_{6} \mathrm{H}_{4} \mathrm{NNNC}_{6} \mathrm{H}_{4} \mathrm{NO}_{2}\right)\left(\mathrm{C}_{18} \mathrm{H}_{15} \mathrm{P}\right)_{2}\right]$, the first mononuclear triazenide complex of $\mathrm{Cu}(\mathrm{I})$ including a $\left[\mathrm{Cu}\left(\mathrm{PPh}_{3}\right)_{2}\right]^{+}$fragment. The crystals belong to the monoclinic system, space group $P 2_{1} / c$ with the cell dimensions $a=$ 15.8852(3), $b=11.9539(3), c=23.2094(6) \AA, \beta=94.646(1)^{\circ}, V=4392.75(18) \AA^{3}, Z=4$. The crystal structure reveals a bidimensional assembling of complex molecules linked through intermolecular non-classical C-H... O hydrogen bonds.
\end{abstract}

(Received October 7, 2005; Accepted March 8, 2006; Published on web May 31, 2006)

Triazenide ligands have attracted considerable attention because of the versatility of their coordination forms, yielding a variety of coordination compounds with large structural diversity. Although metal complexes with 1,3-diaryl-substituted triazenide ligands, [ArNNNAr] $]^{-}$, have been extensively investigated in the

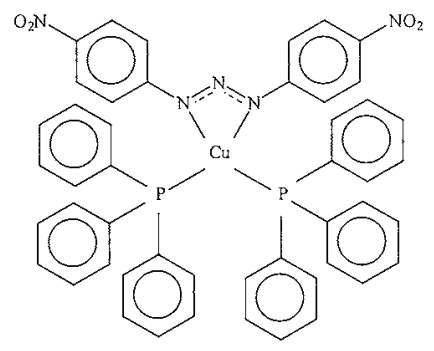

Fig. 1 Chemical diagram.

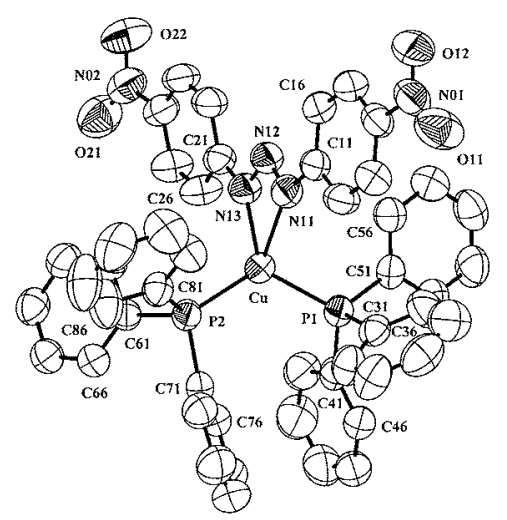

Fig. 2 Molecular structure of the $\mathrm{Cu}(\mathrm{I})$ complex with the atomnumbering scheme. Displacement ellipsoids are drawn at the $50 \%$ probability level and $\mathrm{H}$ atoms have been omitted for clarity.

$\doteqdot$ To whom correspondence should be addressed. E-mail: hoerner@smail.ufsm.br past, to date only five monocatenated diaryltriazenide complexes with copper(I) have been characterized by singlecrystal X-ray diffraction: bis $\left(\mu_{2}\right.$-(diazoaminobenzene)-dicopper(I) ${ }^{1,2} \quad \operatorname{bis}\left(\mu_{2}-1,3\right.$-bis(2-methoxycarbonylphenyl)triazenide- $\left.N, N^{\prime}, O\right)$ dicopper(I), ${ }^{3} \quad$ tetrakis $\left(\mu_{2}-1,3\right.$-bis $(4-$ trifluoromethylphenyl)triazenido)- $\left.N, N^{\prime}\right)$-tetracopper(I), and tetrakis( $\mu_{2}$-1,3-bis(4-fluorophenyl)triazenido)tetracopper(I). ${ }^{4} \mathrm{~A}$

Table 1 Crystal and experimental data

Formula: $\mathrm{C}_{48} \mathrm{H}_{38} \mathrm{CuN}_{5} \mathrm{O}_{4} \mathrm{P}_{2}$

Formula weight: 874.31

Crystal system: monoclinic

Space group: $P 2_{1} / c \quad Z=4$

$a=15.8852(3) \AA$

$b=11.9539(3) \AA$

$c=23.2094(6) \AA$

$\beta=94.646(1)^{\circ}$

$V=4392.75(18) \AA^{3}$

$D_{\text {x }}=1.322 \mathrm{~g} / \mathrm{cm}^{3}$

Absorption coefficient $=0.620 \mathrm{~mm}^{-1}$

$F\left(\begin{array}{lll}0 & 0 & 0\end{array}\right)=1808$

Crystal dimension $(\mathrm{mm}): 0.22 \times 0.12 \times 0.07$

$R=0.0446$

$R w=0.1086$

$\theta$ range for data collection: 3.14 to $24.89^{\circ}$

Goodness-of-fit $=1.004$

$(\Delta \rho)_{\max }=0.285$ e. $\AA^{-3}$

$(\Delta \rho)_{\min }=-0.240 \mathrm{e} . \AA^{-3}$

No.of reflection used $=7562$

No. of parameter $=542$

Data collection: Nonius KappaCCD area-detector diffractometer ${ }^{8}$

Cell refinement: HKL SCALEPACK ${ }^{9}$

Data reduction: HKL DENZO ${ }^{8}$ and SCALEPACK

Molecular graphics: DIAMOND ${ }^{10}$

Absorption correction: analytical ${ }^{11}$

CCDC 285578 contains the supplementary crystallographic data for this paper. These data can be obtained free of charge from the Cambridge Crystallographic Data Centre via www.ccdc.cam.ac. uk/data_request/cif. 
Table 2 Selected bond lengths $(\AA)$ and angles $\left({ }^{\circ}\right)$

$\begin{array}{ll}\mathrm{Cu}-\mathrm{N}(13) & 2.092(3) \\ \mathrm{Cu}-\mathrm{N}(11) & 2.237(3) \\ \mathrm{Cu}-\mathrm{P}(2) & 2.2494(10) \\ \mathrm{Cu}-\mathrm{P}(1) & 2.2525(10) \\ \mathrm{N}(11)-\mathrm{N}(12) & 1.306(4) \\ \mathrm{N}(12)-\mathrm{N}(13) & 1.308(4) \\ & \\ \mathrm{N}(13)-\mathrm{Cu}-\mathrm{N}(11) & 58.06(11) \\ \mathrm{N}(13)-\mathrm{Cu}-\mathrm{P}(2) & 116.58(9) \\ \mathrm{N}(11)-\mathrm{Cu}-\mathrm{P}(2) & 119.09(8) \\ \mathrm{N}(13)-\mathrm{Cu}-\mathrm{P}(1) & 119.07(9) \\ \mathrm{N}(11)-\mathrm{Cu}-\mathrm{P}(1) & 104.67(8) \\ \mathrm{P}(2)-\mathrm{Cu}-\mathrm{P}(1) & 121.47(4) \\ \mathrm{N}(11)-\mathrm{N}(12)-\mathrm{N}(13) & 107.3(3) \\ & \end{array}$

review of the literature showed that no X-ray crystal data have been reported on a mononuclear triazenide complex with copper(I). In this work, we report on the crystal structure of the title complex, (I), (Fig. 1) based on a single-crystal X-ray structural analysis.

The synthesis of the title complex included reagents and solvents of reagent grade, which were used without further purification. 1,3-Bis(4-nitrophenyl)triazene and $\left[\mathrm{CuCl}\left(\mathrm{PPh}_{3}\right)_{3}\right]$ were prepared according to reported methods. ${ }^{5}$ 1,3-Bis(4nitrophenyl)triazene $(28.7 \mathrm{mg}, 0.1 \mathrm{mmol})$ was dissolved in methanol $(20 \mathrm{~mL})$ and treated with small portions of metallic sodium powder, resulting in an intense-red mixture. Excess sodium metal was filtered off and small portions of powdered $\left[\mathrm{CuCl}\left(\mathrm{PPh}_{3}\right)_{3}\right] \quad(88.6 \mathrm{mg}, \quad 0.1 \mathrm{mmol})$ were added under continuous stirring while the color of the reaction mixture changed to orange-red. Stirring was continued for $2 \mathrm{~h}$. An orange-red microcrystalline solid, insoluble in the common organic solvents, was filtered off. Orange-red block-shaped crystals of $\left[\mathrm{Cu}\left(\mathrm{O}_{2} \mathrm{NC}_{6} \mathrm{H}_{4} \mathrm{NNNC}_{6} \mathrm{H}_{4} \mathrm{NO}_{2}\right)\left(\mathrm{C}_{18} \mathrm{H}_{15} \mathrm{P}\right)_{2}\right]$ (I) suitable for $\mathrm{X}$-ray diffraction were obtained by slow evaporation of the filtrate at room temperature. Yield $45 \%(39.3 \mathrm{mg}), \mathrm{m} . \mathrm{p} .190^{\circ} \mathrm{C}$. IR (CsI pellet, $\left.\mathrm{cm}^{-1}\right) 1224.6\left(v_{\text {as }} \mathrm{NNN}\right)$ vs; $1508.1\left(v_{\text {as }} \mathrm{NO}_{2}\right)$ vs; $1330.7\left(v_{\mathrm{s}} \mathrm{NO}_{2}\right)$ vs. (IR data: vs, very strong).

$\mathrm{X}$-ray data were collected by graphite-monochromated Mo $K_{\alpha}$ radiation $(\lambda=0.71073 \AA)$. The crystal and experimental data are listed in Table 1. The structure was solved by direct methods using SHELXS97. ${ }^{6}$ The non-hydrogen atoms were refined anisotropically by the full-matrix least-squares method using SHELXL97. ${ }^{6}$ The positional parameters of the $\mathrm{H}$ atoms were obtained geometrically, with the $\mathrm{C}-\mathrm{H}$ distances fixed $(0.93$ $\AA$ for $\mathrm{Csp}^{2}$ ), and refined as riding on their respective $\mathrm{C}$ atoms, with $U_{\text {iso }}(\mathrm{H})=1.2 U_{\text {eq }}\left(\mathrm{Csp}^{2}\right)$. The nitro $\mathrm{O}$ atoms have elongated displacement ellipsoids (Fig. 2). Split peaks for these atoms were not observed, and consequently a disorder model was not used in the refinement. Selected bond distances and angles are given in Table 2. Figure 2 represents the molecular structure of the title complex.

The crystal structure of (I) consists of discrete mononuclear complexes in which the $\mathrm{Cu}(\mathrm{I})$ ion has a distorted tetrahedral coordination environment. One deprotonated 1,3-bis(4nitrophenyl)triazenide ion acts as a (N11)- $\eta^{1}$,(N13)- $\eta^{1}$ bidentate (four-electron donor) ligand. Two neutral triphenylphosphine molecules complete the coordination sphere of the metal ion to a distorted tetrahedron. The $\mathrm{Cu}-\mathrm{N} 11$ and $\mathrm{Cu}-\mathrm{N} 13$ distances are significantly different at 2.237(3) and 2.092(3) $\AA$, and can be compared to those $\mathrm{Cu}-\mathrm{N}$ distances in $\operatorname{bis}\left(\mu_{2}-1,3-\operatorname{bis}(2-\right.$ methoxycarbonylphenyl)triazenide- $N, N^{\prime}, O$ )-di-copper(I) of 1.909(4) and 1.905(4) . $^{3}$ Due to the fact that the 1,3-bis(4nitrophenyl)triazenide ion acts as a bidentate ligand in complex(I), the copper-nitrogen distances are longer than as those observed in $\operatorname{bis}\left(\mu_{2}-1,3-b i s(2-\right.$ methoxycarbonylphenyl)triazenide- $\left.N, N^{\prime}, O\right)$ dicopper(I), in which two triazenide ions bridges two copper centers as monodentate ligands. On the other hand, the $\mathrm{Cu}-\mathrm{P}$ distances in complex(I) are very similar at 2.2494(10) and 2.2525(10) $\AA$, and can be compared to those $\mathrm{Cu}-\mathrm{P}$ distances in $\left[\mathrm{Cu}\left(\mathrm{N}_{3}\right)(\mathrm{dmpymtH})\left(\mathrm{PH}_{3}\right)_{2}\right]$ [dmpymtH = 4,6(dimethylpyrimidine-2(1H)-thione] of 2.2658(11) and 2.2799(11) . $^{7}$ The $\mathrm{P} 1-\mathrm{Cu}-\mathrm{P} 2$ angle of $121.47^{\circ}$ observed in complex(I) is smaller than the correspondent angle of $124.96(4)^{\circ}$ observed in $\left[\mathrm{Cu}\left(\mathrm{N}_{3}\right)(\mathrm{dmpymtH})\left(\mathrm{PH}_{3}\right)_{2}\right]$. The smaller $\mathrm{P}-\mathrm{Cu}-\mathrm{P}$ angle observed in complex(I) can be attributed to steric effects of the 1,3-bis(4nitrophenyl)triazenide ligand on both the triphenylphosphine ligands in the copper coordination sphere.

Complexes in the structure of (I) are linked by hydrogen bridges in two dimensions. The $\mathrm{O}$ atoms of $\mathrm{NO}_{2}$ groups of one complex form non-classical $\mathrm{C}-\mathrm{H} \ldots \mathrm{O}$ hydrogen bonds to the $\mathrm{H}$ atoms of the $\mathrm{PPh}_{3}$ groups of each four neighbored complexes. The linked complexes are spread out parallel to the $b$-c-plane: $\left[\mathrm{C} 63 \cdots \mathrm{O} 12^{\prime}=3.089(6) \AA\right.$ and $\mathrm{C} 63-\mathrm{H} 63 \cdots \mathrm{O} 12^{\prime}=122^{\circ}$; symmetry code: (') $1-x, 1-y,-z], \quad\left[\mathrm{C} 53 \cdots \mathrm{O} 22^{\prime \prime}=3.171(6) \AA\right.$ and

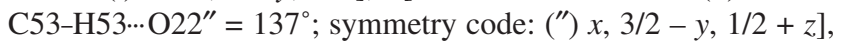
$\left[\mathrm{C} 54 \cdots \mathrm{O} 11^{\prime \prime \prime}=3.279(6) \AA\right.$ and $\mathrm{C} 54-\mathrm{H} 54 \cdots \mathrm{O} 11^{\prime \prime \prime}=150^{\circ}$; symmetry code: ("'I) $1-x, 1 / 2+y, 1 / 2-z]$. This expanded system of intermolecular hydrogen bonds probably causes the unexpected insolubility of the compound.

\section{Acknowledgements}

This work received partial support from $\mathrm{CNPq}$ (proc. 475294/2004-1). M. H. thanks CNPq (proc. 301310/2003-3) and J. S. B. thanks CAPES for grants.

\section{References}

1. I. D. Brown and J. D. Dunitz, Acta Crystallogr., 1961, 14, 480.

2. L. R. Falvello, E. P. Urriolabeitia, U. Mukhopadhyay, and D. Ray, Acta Crystallogr., 1999, C55, 170.

3. G. Rios-Moreno, G. Aguirre, M. Parra-Hake, and P. J. Walsh, Polyhedron, 2003, 22, 563.

4. E. Hartmann and J. Strähle, Z. Naturforsch., 1988, 43B, 818; Z. Anorg. Allg. Chem., 1990, 583, 31.

5. M. Hörner, L. Bresolin, J. Bordinhão, E. Hartmann, and J. Strähle, Acta Crystallogr., 2003, C59, o426; H. A. Tayim, A. Bouldoukian, and F. Awad, J. Inorg. Nucl. Chem., 1970, 32, 3799.

6. G. M. Sheldrick, SHELXS97 and SHELXL97, 1997, University of Göttingen, Germany.

7. S. S. Lemos, M. A. Camargo, A. Z. Cardoso, V. M. Deflon, F. H. Försterling, and A. Hagenbach, Polyhedron, 2001, 20, 849.

8. Nonius COLLECT, 1997 - 2000. Nonius BV, Delft, The Netherlands.

9. Z. Otwinowski and W. Minor, "Methods in Enzymology, Macromolecular Crystallography", Part A, ed. C. W. Carter Jr. and R. M. Sweet, Academic Press, New York, 1997, Vol. 276, 307.

10. K. Brandenburg. DIAMOND. 1996, Version 1.1a. Crystal Impact GbR, Bonn, Germany.

11. N. W. Alcock. "Crystallographic Computing", ed. F. R. Ahmed, S. R. Hall, and P. Huber, Munksgaard, Copenhagen, 1970, 271. 